\title{
Biological Improvement of Coal: Formica rufa Enzymes over Mining Fluid and Rumen Liquid
}

\author{
Cemil Koyunoğlu, ${ }^{1,2, *}$, Ece Polat ${ }^{3,4}$ \\ ${ }^{1}$ Institute of Energy, Istanbul Technical University, Turkey \\ ${ }^{2}$ Department of Energy Systems Engineering, Yalova University, Turkey \\ ${ }^{3}$ Department of Environmental Engineering, Istanbul Technical University, Turkey \\ ${ }^{4}$ Department of Environmental Engineering, Gebze Technical University, Turkey
}

Copyright $₫ 2017$ by authors, all rights reserved. Authors agree that this article remains permanently open access under the terms of the Creative Commons Attribution License 4.0 International License

\begin{abstract}
Biological remediation of coal is based on the principle that the coal is converted to water-soluble products of various molecular weights to neutral $\mathrm{pH}$ or alkaline conditions. There are many studies in the related literature on the process of conversion of the cargo into water-soluble molecules. In this study, Azdavay Coal which was a key energy raw material of Kardemir Demir Çelik Factory was examined using a novel biological treatment method. In the biological treatment of Azdavay Coal, coal was treated with Azdavay mining fluid, rumen liquid, and Formica rufa enzymes. In the results, an increase in the -OH group and a decrease in the fixed carbon value have occurred and the best efficient method was found as 2 days long Formica rufa treatment.
\end{abstract}

Keywords Azdavay Coal, Biological Improvement, Formica rufa, Rumen Liquid

\section{Introduction}

In previous times, coal was important just for as being energy source of production processes, but nowadays based on the complicated structure of coal conversion processes compared to natural gas and oil production processes; it was obliged to improve the coal as a part of energy purposes [1]. Coal preparation have importance based on technologic and economic purposes.

Coal is needed to be improved to reach feasible and ecologically friendly combustion and energy generation. For the improvement of coal, there are many applicable methods such as crushing/grinding, sieving/sizing, dewatering, and washing. With these technologies, it is possible to reduce calorific value by decreasing some of the inorganic substances (ash-forming minerals and pyritic sulfur) from coal and/or decreasing the moisture content during the coal formation process and during production processes [2].

Contaminants such as ash-forming minerals and sulfur, which remain as a part of coal, create problems in the application of coal, especially in combustion processes. While some of the minerals in the coal are mixed with the coal during the coal formation process, some are mixed with the coal during production process. Impurities created during the formation of coal can be dispersed in the very small size of coal and can cause major drawbacks in terms of coal washing [2]. Some of these impurities are part of the organic structure, such as organic sulfur and ash. Mineral materials which are in the form of large structures or thick intercalations during the coal formation process can be removed from the coal in a certain way using coal preparation and healing technologies [2].

Biological improvement of coal is based on the conversion of the biologically curable part of the coal into water-soluble products under neutral or alkaline conditions [3]. In literature, there are many studies about the conversion of the coal into the water-soluble products [3-8]. Moreover, less coal consumption is still important objectives of the energy sector and biologically improved coal can achieve this expectation. There are many biological processes that can be applied with coal.

Anaerobic processes can be defined as the break down organic substances by converting them into end products such as $\mathrm{CH}_{4}, \mathrm{CO}_{2}$, and microorganism biomass. In the anaerobic treatment process, the organic substance is used both as an electron donor (oxidation) and as an electron acceptor (synthesis). Anaerobic biochemical dissociation process consists of hydrolysis, acidogenesis, acetogenesis and methanogenesis steps. In each step, several types of microorganisms from fungi to bacteria plays important role for degradation process [9]. Methanogenesis is an important step for methane and energy generation. The energy content of biogas mainly consist of methane can be used to produce electricity, steam, and vehicle fuel efficiently [10]. 
Aerobic processes are alternative to anaerobic processing of the coal and based on oxidative bio-solubilization which is related to the aromatic ring hydroxylation reactions [11]. However, due to its external oxygen and aeration need and its cause a bad quality coal nor preferred method.

\section{Materials and Methods}

The whole biological improvement of coal was conducted in Solid Waste Laboratory of Istanbul Technical University Department of Environmental Engineering.

\subsection{Coal Preparation}

Azdavay Coal, taken from Kardemir, was ground with an annular grinding device before using it for anaerobic improvement. Then, $5 \pm 0.1 \mathrm{~g}$ was weighed and was sieved to a range of $+63 \mu \mathrm{m}$ to $-125 \mu \mathrm{m}$ and then added to $120 \mathrm{ml}$ serum bottles.

\subsection{Seed Culture}

Azdavay mining fluid (AS) contains microbiological culture. 16 liters of fluid was brought to ITU Solid Waste Laboratory in glass bottles.

Rumen liquid (RS) was taken from Küçükçekmece slaughterhouse. Formica rufa (FR) ants were brought ITU Solid Waste Laboratory in glass bottles containing 180 pieces of wood taken from Belgrad forest.

\subsection{Media Preparation}

Solution I, Solution II, salt, resazurin, stock acid I, stock acid II and deionized water were used for the preparation of the medium required for the anaerobic processes. These chemicals were boiled in a $2 \mathrm{~L}$ glass bottle and then cooled to room temperature in the ice bath. During cooling, 2 bar $\mathrm{N}_{2}$ gas was passed through to provide anaerobic conditions.

After the solution was cooled to room temperature, Vitamin and $\mathrm{NaHCO}_{3}$ were added into $120 \mathrm{ml}$ serum bottles ( 3 bottles prepared for each waiting period) $45 \mathrm{ml}$ of media for RS and $1 \mathrm{ml}$ of $45 \mathrm{ml}$ of media (Gupta and Gupta, 2014) for FR were added. The mouth of each serum bottle was pressurized with boiler-disinfected rubber stoppers and the tops were pressed with an aluminum cap. Anaerobic condition was achieved by passing each bottle through a 1 minute $\mathrm{N}_{2}$ gas with needle-tipped nitrogen outlet.

Prepared serum bottles were kept in a room set at $37^{\circ} \mathrm{C}$. After 1 minute rinsing, initial measurements were taken with a manual manometer. The pressure was measured by shaking with a hand for 1 minute every two days. Serum bottles taken at designated times for the measurement were taken to the cold room to stop anaerobic activity.

\subsection{Coal Washing Process}

Washing operations were carried out by determining serum vials with increased pressure according to nitrogen gas measurements. In order to determine wash amount, each vaccine type washing with double distilled water and centrifugation applied.

\subsection{Microbiological Analysis}

Microbiological analysis was carried out according to ASTM E 112 standard to determine whether the microbiological culture remains in the liquid separated from the solid phase (was done as part of coal washing process), whether the cleaning has been completed.

The specimens taken with a plastic pipette were allowed to air dry on the slides. After drying, Crystal, Gram iodine, 95\% ethanol solution and safranin solution applied respectively as a procedure of gram staining.

The blue-pink colored (Gram + ) and red-pink (Gram -) colored cells detected at $10 \mathrm{x}$ and $40 \mathrm{x}$ under the light microscope.

\subsection{Other Analysis}

Petrographic analysis, elemental analysis, and TGA analysis was performed to characterize the coal and biological improvement methods. Petrographic analyses were carried out in MTA Ankara Organic Petrography Laboratory. TGA analyzes were carried out in Inonu University Department of Chemistry under Shimadzu System 50 DTA and by heating to $900^{\circ} \mathrm{C}$ at a heating rate of $10^{\circ} \mathrm{C} / \mathrm{min}$ in nitrogen atmosphere. Elemental analyses were performed at İnönü University Scientific Research Center (IBTAM) with the LECO brand CHNS device.

\section{Results}

\subsection{Calculation of Maximum $\mathrm{CO}_{2}$ Emission and Elemental Analysis}

To calculate the maximum $\mathrm{CO}_{2}$ output in anaerobic improvement of coal the above equation was used [12].

$$
\begin{gathered}
\mathrm{C}_{c} \mathrm{H}_{h} \mathrm{O}_{o} \mathrm{~N}_{n} \mathrm{~S}_{s}+y\left(\mathrm{H}_{2} \mathrm{O}\right) \rightarrow x\left(\mathrm{CH}_{3}\right)+(\mathrm{c}-x) \mathrm{CO}_{2}+ \\
n\left(\mathrm{NH}_{3}\right)+s\left(\mathrm{H}_{2} \mathrm{~S}\right) \\
\mathrm{x}=(4 \mathrm{c}+\mathrm{h}-2 \mathrm{o}-3 \mathrm{n}-2 \mathrm{~s}) / 8 \\
\mathrm{y}=(4 \mathrm{c}-\mathrm{h}-2 \mathrm{o}+3 \mathrm{n}+2 \mathrm{~s}) / 4 .
\end{gathered}
$$

In order to improve the Azdavay coal with Azdavay mining fluid and to find the optimum time for carbon removal, tests that were applied at 7th, 11th and 22th days were evaluated based on their $\mathrm{CO}_{2}$ emission amounts and the data is shown in Table 1. 
Table 1. Improvement results of Azdavay mining fluid (AS).

\begin{tabular}{|c|c|c|c|}
\hline & Reference & 11th days & 22th days \\
\hline $\mathrm{C}$ & 73.77 & 64.06 & 63.77 \\
\hline $\mathrm{H}$ & 3.31 & 2.9 & 2.92 \\
\hline $\mathrm{N}$ & 1.3 & 1.37 & 1.29 \\
\hline $\mathrm{S}$ & 0.78 & 0.91 & 0.85 \\
\hline $\mathrm{O}$ & 20.84 & 30.76 & 31.17 \\
\hline Max. $\mathrm{CO}_{2}$ emission (mole) & 3.03 & 2.83 & 2.82 \\
\hline Max. $\mathrm{CO}_{2}$ production (mole) & - & 0.195 & 0.206 \\
\hline
\end{tabular}

The maximum amount of $\mathrm{CO}_{2}$ that can be produced from coal from day 22 to day 11 did not change significantly, to 0.195 and 0.206 mole, respectively. For this reason, the minimum period for Azdavay mining fluid can be defined as 11 days. Studies in the literature suggest that the activity of wood insects and rumen fluid in anaerobic applications is more effective than mine fluid $[3,8,13]$.

Base on the literature data, rumen liquid (RS) and Formica rufa (RF) were applied up to 2 days for biological improvement purposes. Maximum $\mathrm{CO}_{2}$ output obtained is 0.480 and 0.770 mole on the 2 nd and 11 th days of the rumen fluid, respectively (Tab. 2).

Table 2. Improvement results of rumen fluid (RS).

\begin{tabular}{|c|c|c|c|}
\hline & Reference & 2nd days & 11th days \\
\hline $\mathrm{C}$ & 73.77 & 57.10 & 46.19 \\
\hline $\mathrm{H}$ & 3.31 & 3.64 & 3.66 \\
\hline $\mathrm{N}$ & 1.3 & 1.35 & 0.89 \\
\hline $\mathrm{S}$ & 0.78 & 0.66 & 0.48 \\
\hline $\mathrm{O}$ & 20.84 & 37.25 & 48.78 \\
\hline Max. $\mathrm{CO}_{2}$ emission (mole) & 3.03 & 2.55 & 2.26 \\
\hline Max. $\mathrm{CO}_{2}$ production (mole) & - & 0.480 & 0.770 \\
\hline
\end{tabular}

Compared to 11 th day of the Azdavay mining fluid (AS), the maximum $\mathrm{CO}_{2}$ output value of the second day of the rumen liquid is much higher, and thus the most appropriate of seed can be the second day of the RS. If the maximum $\mathrm{CO}_{2}$ production values on the 2 nd and 11 th days of FR are compared, as shown in Table 3, there was no significant change between these days.

Table 3. Improvement results of Formica rufa (FR).

\begin{tabular}{|c|c|c|c|}
\hline & Reference & 2nd days & 11th days \\
\hline $\mathrm{C}$ & 73.77 & 51.78 & 51.31 \\
\hline $\mathrm{H}$ & 3.31 & 3.67 & 3.70 \\
\hline $\mathrm{N}$ & 1.3 & 1.06 & 1.05 \\
\hline $\mathrm{S}$ & 0.78 & 0.60 & 0.54 \\
\hline $\mathrm{O}$ & 20.84 & 42.9 & 43.4 \\
\hline Max. $\mathrm{CO}_{2}$ emission (mole) & 3.03 & 2.40 & 2.39 \\
\hline Max. $\mathrm{CO}_{2}$ production (mole) & - & 0.624 & 0.641 \\
\hline
\end{tabular}

Based on these data, the Formica rufa (FR) was chosen the best appropriate seed for the biological improvement of the coal due to high $\mathrm{CO}_{2}$ production potential in terms of mole.

\subsection{Gas Measurements}

In the literature, it was stated that rumen liquid and Formica rufa has higher efficiency on the biomethane production as compared to mine liquid so that gas measurements for AS was done at 11th and 22th days but, for RS and FR measurements were applied at 2nd day, 4th day and 7 th of the biological improvement studies $[3,8$, 13].

The pressure change of the Azdavay mining liquid (AS) was shown in Figure 1.The Figure 2 shows the pressure change of rumen liquid. From the figure, it was observed that on the 4 th and 7 th days there was a significant decrease in the pressure.

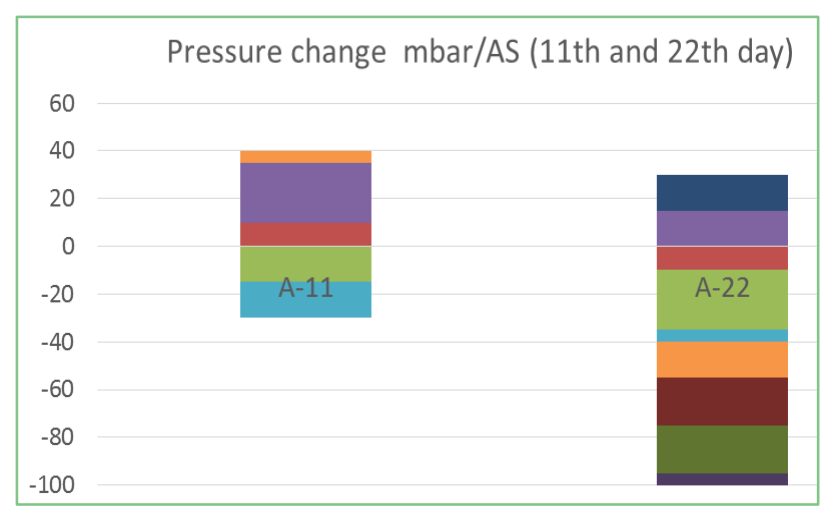

Figure 1. Pressure change in AS (A-11: 11 days, A-22: 22 days).

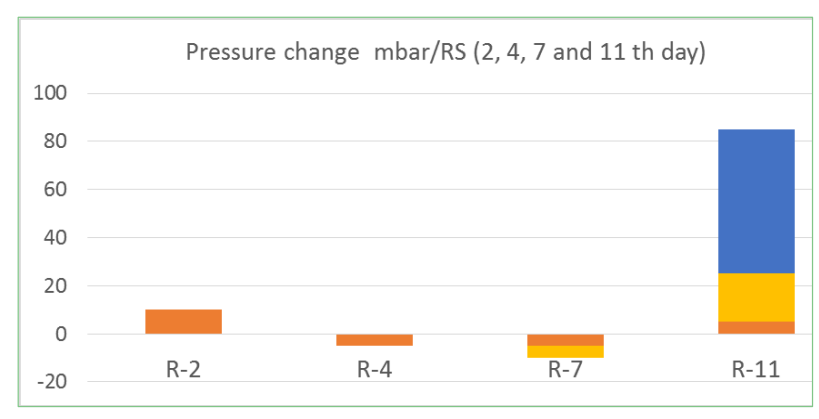

Figure 2. Pressure change in RS (R-2: 2 days).

Moreover, for Formica rufa (FR) same decrease was observed at days 4 and 7 (Fig.3). So that for TGA analyzes of Formica rufa (FR) and rumen liquid (RS) 2nd and 11 th-day samples were analyzed.

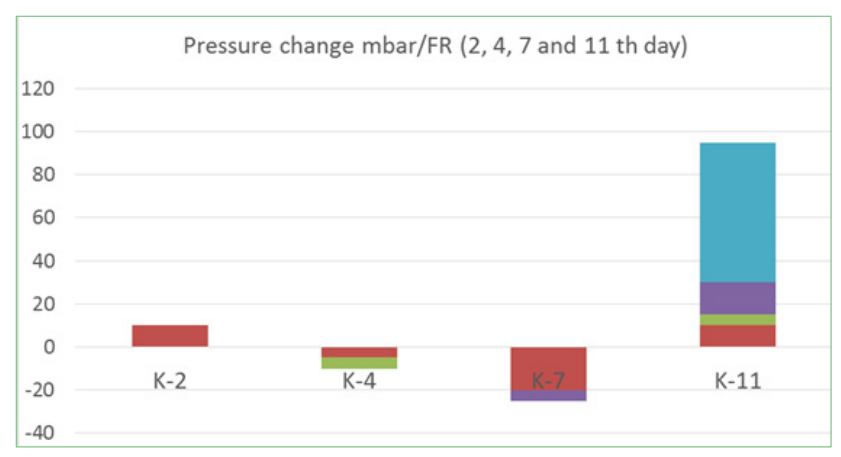

Figure 3. Pressure change in FR (K-2: 2 days). 


\subsection{Optimization of Washing Step}

Colonies and cells that are observed under light microscope and using the Gram staining technique has showed that for AS and RS 6th washing step and for FR 12th washing step was appropriate for the no colony observation in microscopic examination.

\subsection{Petrographic Analyzes}

The Azdavay coal content and maseralls structure was shown in Table 4 and Table 5. The majority of Azdavay coals maseralls structure is composed of Vitrinite and in blast furnaces, $15 \%$ anthracite, $83.5 \%$ lower bituminous coal and $1.5 \%$ pit fuel are used as fuel.

Table 4. Azdavay coals maseralls structure

\begin{tabular}{|c|c|}
\hline Maseralls & $\mathbf{\%}$ \\
\hline Vitrinite & 85.5 \\
\hline Liptinite & 1 \\
\hline Inertinite & 8 \\
\hline Other minerals & 5 \\
\hline Pyrites & 0.5 \\
\hline
\end{tabular}

Table 5. Azdavay coal content.

\begin{tabular}{|c|c|}
\hline Content & $\mathbf{\% ( w / w )}$ \\
\hline Anthracite & 15 \\
\hline Lower bituminous coal & 83.5 \\
\hline Pit coal & 1.5 \\
\hline
\end{tabular}

\subsection{TGA Analyzes}

From TGA analysis of coal samples that were improved by AS, RS, and FR, the data at Table 6 was obtained. The results showed that Azdavay coal has high devolatilization temperature about $600^{\circ} \mathrm{C}$. This can be attributed to $15 \%$ anthracite nature that may negative effect on the biological improvement studies based on its volatility. The fixed carbon of raw coal obtained roughly with \% 60 (dry ash free) however after treatment the value was $\% 5,56$ (dry ash free).

\subsection{The ICP-AES conducted in the Pennsylvania State}

University Chemistry building laboratory with the samples of raw coal and treated coal. After treatment due to the ICP-AES results the compound abundance of $\mathrm{Fe}_{2} \mathrm{O}_{3}$ and $\mathrm{CaO}$ reduced. It means if treated coal mixed with raw coal in the combustion chamber the slagging and fouling effects of burning will be reduced.

Table 6. Devolatilization temperatures of the samples.

\begin{tabular}{|c|c|c|}
\hline & DVT $\left({ }^{\circ} \mathrm{C}\right)$ & $\begin{array}{c}\text { Difference } \\
\left({ }^{\circ} \mathrm{C}\right)\end{array}$ \\
\hline Azdavay coal & 600.26 & \\
\hline AS (11d)* & 553.62 & 46.64 \\
\hline AS $(11 d b)^{* *}$ & 580 & 20.26 \\
\hline $\operatorname{AS}(22 d)^{*}$ & 561.46 & 38.8 \\
\hline AS $(22 d b)^{* *}$ & 575.76 & 24.5 \\
\hline $\operatorname{RS}(2 d)^{*}$ & 546.08 & 54.18 \\
\hline $\operatorname{RS}(2 \mathrm{db})^{* *}$ & 579.51 & 20.75 \\
\hline $\operatorname{RS}(11 d)^{*}$ & 572.41 & 27.85 \\
\hline $\mathrm{RS}(11 \mathrm{db})^{* *}$ & 576.96 & 23.3 \\
\hline FR $(2 d)^{*}$ & 512.1 & 88.16 \\
\hline $\operatorname{FR}(2 \mathrm{db}) * *$ & 580.37 & 19.89 \\
\hline FR (11d)* & 575.79 & 24.47 \\
\hline FR $(11 d b)^{* *}$ & 571.19 & 29.07 \\
\hline
\end{tabular}

DVT $=$ Devolatilization Temperature

* day number of the biological improvement

** blank sample as control

\subsection{FTIR Results}

The FTIR results conducted in the FTIR analysis conducted in the coal utilization lab, the Pennsylvania State University and found more - $\mathrm{OH}$ group in treated coal than raw coal. The detailed results are shown in Figure 4. 


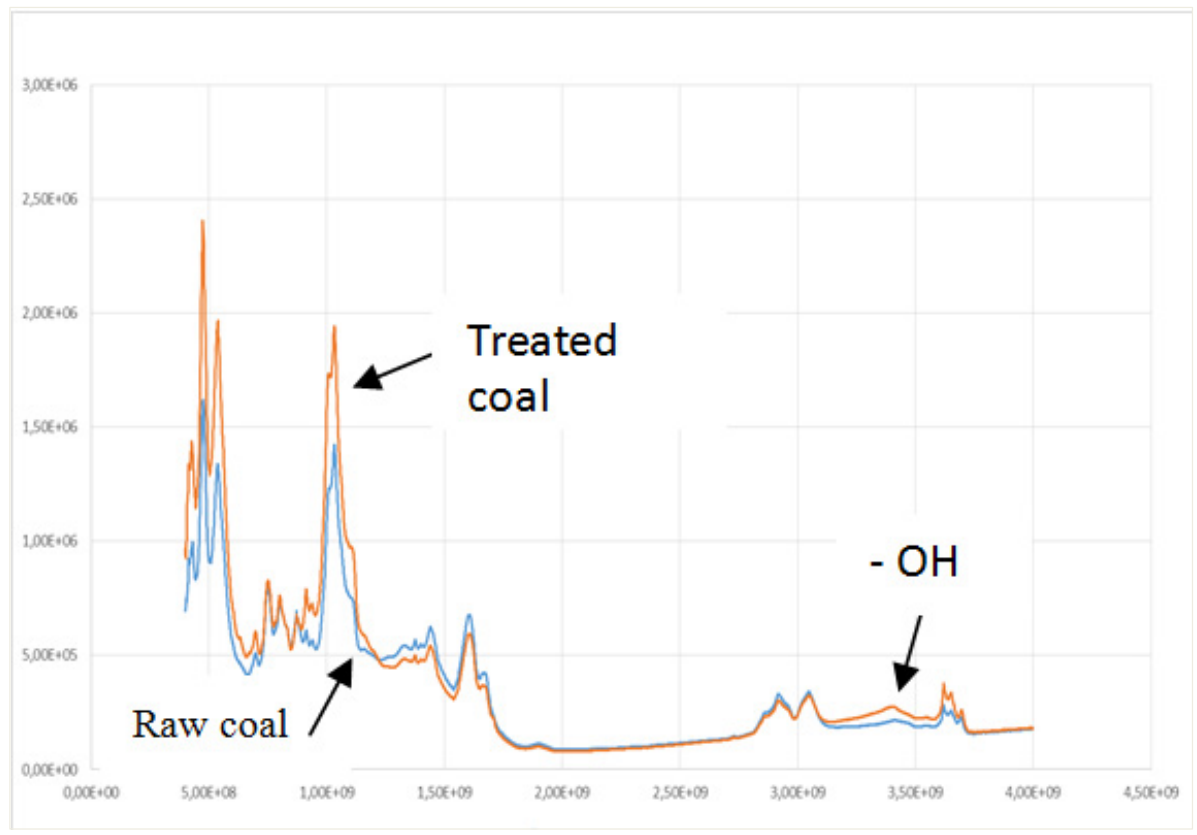

Figure 4. FTIR results of before and after treated coal $\mathrm{x}$-axis is wavenumbers, $\mathrm{cm}^{-1}$.

\section{Conclusions}

When we considered the devolatilization temperature and $\mathrm{CO}_{2}$ emission, Formica rufa (RF) has the highest efficiency on the biological improvement of the Azdavay coal. And after doing $1 \mathrm{~kg}$ of treated coal with RF, TGA analysis gave us the lowest fixed carbon, which means the RF did behave as biogenic, The ICP-AES results show that after treatment with coal if mixes with raw coal the slagging behavior will be reduced. The FT-IR results show that the $-\mathrm{OH}$ group (mainly phenolic) presents the hydrolysis behavior of RF over coal fragments mainly on lignin structure. The type of coal and also the enzymes can be changed for other studies. As a result for a high scale, azdavay type of coal treatment is favorable while using with RF enzymes as well.

\section{Acknowledgements}

The authors are grateful Assist. Prof. Dr. Mahmut Altınbaş (Istanbul Technical University) for his support during this study.

\section{REFERENCES}

[1] M.A. Hassan, S. Yacob, C.W. Chung, Y. Shirai, Y.-T. Hung. Environmental Bioengineering. Humana Press, USA, 2010.

[2] P.D.G. Ateşok. Kömür Hazırlama ve Teknolojisi. Yurt Madenciliğini Geliştirme Vakfı, İstanbul, 2009.

[3] Archtech Inc. Biological Gasification of Coals, U.S. Department of Energy Office of Fossil Energy, Vest Virginia, 1990.
[4] A.P. Torzilli, J.D. Isbister. Comparison of coal solubilization by bacteria and fungi. Biodegradation, 5, 55-62, 1994.

[5] R. Haider, M.A. Ghauri, J.R. SanFilipo, E.J. Jones, W.H. Orem, C.A. Tatu, K. Akhtar, N. Akhtar. Fungal degradation of coal as a pretreatment for methane production. Fuel, 104, 717-725, 2013.

[6] D. Wadhwa, D.K. Sharma. Microbial pretreatment of coals: A tool for solubilization of lignite in organic solvent quinoline. World Journal of Microbiology \& Biotechnology, 14, 751-763, 1998.

[7] U. Hölker, H. Schmiers, S. Grobe, M. Winkelhöfer, M. Polsakiewicz, S. Ludwig, J. Dohse, M. Höfer. Solubilization of low-rank coal by Trichoderma atroviride: Evidence for the involvement of hydrolytic and oxidative enzymes by using 14C-labelled lignite, Journal of Industrial Microbiology \& Biotechnology, 28, 207-212, 2002.

[8] D.L. Wise. Bioprocessing and Biotreatment of Coal, Marcel Dekker, New York, 1990.

[9] M. Altınbaş. Population Dynamics in Butyrate Degrading Communities in Anaerobic Bioreactors. Doctor of Philosophy Thesis, İstanbul Technical University, İstanbul, 2007.

[10] İ. Öztürk. Katı Atık Yönetimi ve AB Uyumlu Uygulamaları. İSTAÇ, İstanbul, 2010.

[11] M.K. Jain, D. Burgdorf, R. Narayan. Anaerobic bioprocessing of Wyodak (USA) coal. Fuel, 70, 573-576, 1991.

[12] P. Bohutskyi, B.K.S. Chow, K.J. Adams, M.J. Betenbaugh, F.C.T. Allnutt, E. J. Bouwera, 2015. Anaerobic digestion of lipid-extracted Auxenochlorella protothecoides biomass for methane generation and nutrient recovery, Bioresource Technology, 183, 229-239, 2015

[13] P. Gupta, A. Gupta. Biogas production from coal via anaerobic fermentation, Fuel, 118, 238-242, 2014. 